\title{
Effect of Information and Communication Technology-induced Multitasking on Academic Performance of University Students in Uganda
}

\author{
Peter Jegrace Jehopio \\ Department of Planning and \\ Applied Statisticshhh \\ Makerere University \\ Uganda
}

\author{
Ronald Wesonga \\ Department of Planning and \\ Applied Statistics \\ Makerere University \\ Uganda
}

\author{
Douglas Andabati Candia \\ Department of Planning and \\ Applied Statistics \\ Makerere University \\ Uganda
}

\begin{abstract}
Numerous researches on information and communication technology (ICT)-induced multitasking among students document a number of unfavourable consequences, such as heightened distraction and less attention, hampered learning and hindered productivity at the expense of better academic performance. This study focused on the effect of information and communication technology induced multitasking on academic performance of university students in Uganda. To this end, primary data were collected during the month of May 2016 using stratified cluster sample design. A self-reported questionnaire was used to collect data from 312 students of Makerere University who participated in the study. Through structural equation modelling (SEM), it was demonstrated that ICT-induced multitasking does not affect academic performance directly but through self-regulation, attention span, emotional control and productivity focus. Nonetheless, multitasking does not always have negative consequences. To a majority of students, multitasking provides emotional satisfaction and enjoyment, which do correlate positively with good academic performance. Indeed, multitasking can be an effective use of time when well-regulated and an efficient tool in problem solving. Multitasking may only be indicative of the changing nature of norms. Traditionally, one was expected to give and receive undivided attention when talking in a face-to-face conversation with another; yet new norms are evolving for the networked society, such as responding to text messages promptly. To buffer the negative effect of ICT-induced multitasking on academic performance, one needs a facility with a good degree of self-regulation, attention span, emotional control and productivity focus.
\end{abstract}

Keywords: ICT; SEM; multitasking; academic performance; technology-induced; Uganda

\section{INTRODUCTION}

Students tend to multitask very often during learning activities[1]. Common multitasking activities during learning are social networking, surfing, chatting, texting, tweeting, downloading music and movies, listening to music, studying another lesson, e-mailing, video gaming, note-taking, eating, and drinking [2]. Research on information and communication technology (ICT)-induced multitasking among students documents a number of unlikeable outcomes, such as heightened distraction and less attention, hampered learning and hindered productivity at the expense of better academic performance [3-7] [8] [9, 10] $[11,12][9,13]$. Nonetheless, other recent studies suggest that multitasking does not always have negative outcomes and may even have beneficial cognitive outcomes [14] [15].

The effect of information and communication technology induced multitasking on academic performance of university students in Uganda was investigated. To this end, through stratified cluster sample design, a self-reported questionnaire was used to collect data from 312 students of Makerere University. Moving structural equation modelling (SEM), it was demonstrated that ICT-induced multitasking does not affect academic performance directly but through self-regulation, attention span, emotional control and productivity focus.

\subsection{Literature Review}

Technology-induced multitasking and its damaging influence on academic performance have been widely studied [16] [17] [9] [13]. Further, research on information and communication technology (ICT)-induced multitasking among students documents a number of distasteful consequences, such as heightened distraction and less attention, hampered learning and hindered productivity at the expense of better academic performance [3] [4] [5] [69] [10] $[9,13]$. With the ubiquity of cellular connection, text messaging, social media and the Internet, the modern multitasker is consistently engaged and always "on" at previously unimagined levels [18]. Studies show that a multitasking mind is one which is highly compromised: it juggles, divides, and sacrifices key mental faculties, often at the expense of proper information processing and encoding [19] [20]. Multitasking is known to impair attention [21]. Additionally, multitasking is often characterized by staying up late at night [22], which often positively correlates with lower levels of academic success [23]. 
Multitasking can be defined as being exposed to different information sources and switching between different media [24], which may be either sequential or concurrent based on the time spent on each task before switching to another. If the switching between the tasks is very short in duration (say, from attending a lecture being delivered to taking notes on the lecture), then that is concurrent multitasking. However, if the switches occur in longer durations (say, from attending a lecture being delivered to surfing the Internet), then that is sequential multitasking. It has been registered that individuals "engage in multitasking behaviour despite their metacognitive judgment about the performance costs [25] [26]. In contrast, [21]found that "self-regulated students were more likely to sustain their attention on classroom learning, and therefore less likely to text-message during class," i.e. self-regulated students are unlikely to multitask.

Students tend to multitask very often during learning activities [1]. Common multitasking activities during learning are social networking, surfing, chatting, texting, tweeting, downloading music and movies, listening to music, studying another lesson, e-mailing, video gaming, note-taking, eating, and drinking [2]. In related studies, [27] found that students switch tasks an average of 27 times per hour. [11] reported that students multitask 42 percent of class time. [28] found that 84 percent of college students engage in non-learning related media multitasking behaviours during lecture. Besides, [9] found that students seated near multitasking peers were consistently distracted and performed worse on retention measures compared to those sitting near students who were not multitasking.

Findings suggest that students' technology use is highly attributed to their anxiety without technology and dependency on technology, rather than any actual preference for multitasking [5] [29]. Apparently, the driving force behind multitasking is emotional rewards gained even at the cost of learning [26] [30] [26]. To this point, numerous studies have examined the relationship between anxiety and media multitasking [30]. Considering the documented value of social connection and social capital, this neurological dynamic may explain common research findings in which socially focused forms of multitasking and distraction, such as Facebook and Twitter, are often the most pervasive multitasking endeavour [31]. [32] noted that compulsive texting shares features with their compulsive Internet use given that both enable social interactions and have similar reasons for use, such as allowing for rapid textbased communication that promotes multitasking. An important conclusion from the study was that females would endorse greater frequency of texting compared to males. Indeed, [33]found that females do handle multitasking better than males. Also, [34] found that females were more susceptible to multitask compared to males and the female that engage in multitasking are more likely to have difficulties with academics [35].

Technology-induced multitasking resides within the construct of attentional control [13], and within the broader framework of self-regulation [36]. Attentional control is the ability to sustain deep and focused cognitive attention [10]. Even when students did not actively engage in multitasking, they reported that other students' laptops used in class were perceived as a distraction [37] [9]. Multitaskers are likely to give less attention to immediate, face-to-face communication because they are also thinking about their social network. A related concept is that of polyconsciousness, in which people's access to communication technologies can divide consciousness between immediate ("here and now") interaction settings and more distant settings, which undermines the immediate interaction conversation [38]. The implication of the foregoing discourse is that multi-tasking, divided attention, and the presence of a cell phone may interfere with one's ability to become acquainted with another.

At the same time, several recent studies suggest that multitasking does not always have negative outcomes and may even have beneficial cognitive outcomes [15]. For example, [39]found no significant correlation between media multitasking and a range of psychosocial well-being factors, including emotional positivity, sociability, and impulsivity. In other studies, even positive effects of media multitasking on well-being have been suggested. For example, interacting with family members while viewing television enhanced children's prosocial behaviour, and media multitasking was positively correlated with university students' emotional satisfaction, albeit at the cost of cognitive performance [40]. To be fair, multitasking is necessary for certain professions and is an indisputable phenomenon in education and life [13]. For example, [14] demonstrated that listening to a pleasant music while performing an academic test helped students to overcome stress, to devote more time to more stressful and more complicated task and the grades were higher. Multitasking can be an efficient use of time; a relatively manageable endeavour when necessary; or, when well monitored or well-regulated and, an effective tool in problem solving [41]. For example, multi-tasking can effectively provide a necessary avenue to interact with multiple others all at once in order to accomplish various goals [42]. In addition, certain people prefer to switch between multiple tasks within the same time block, and such "polychronicoriented" individuals can be more satisfied with work that involves multi-tasking[43]. Furthermore, people who are hyper-connected generally report that they do not have problems attending to everyday tasks and inter-personal relationships [44]. It may be a question of changing nature of norms, traditionally people were expected to give and receive undivided attention when talking in face-to-face conversation with another, yet new norms are being developed for the networked society, such as responding to text messages promptly [45]. [46]concluded that students who multitask perform better academically.

In effect, contemporary students are described as digital natives (homo zappiens) and effective multitaskers. Digital natives [47] are individuals who are surrounded by digital technologies [48]. The ability to multitask across various multimedia environments is regarded as a significant characteristic of digital natives [49]. Other common features include effective communication, self-directed learning, and digital thinking [50] [47] [49]. Furthermore, some believe that the brains and cognitive capacity of those engaged in frequent multitasking will expand and adapt as a result of the behaviour, which may help them become "nimble, quick-acting multitaskers"'[51], who are able to manage signals from multiple sources at a time and are well 
prepared for careers in the information industry using technology.

Time management skill is an important aspect of behaviour for self-regulation, which involves setting goals, prioritizing, time estimation and problem solving [6] and as an intervening variable may explain the influence of multitasking on academic performance. If an individual has a good plan of what to do, he may not be distracted by other media activities. In addition, time management could buffer the negative effect of media multitasking. [52] found that many college students report that they were unable to go more than 10 minutes without checking their laptop, smartphone, tablet or e-reader. Many students pause in their learning activity to read and reply immediately to incoming text messages, or browse online while preparing homework $[53,54]$. Research has demonstrated that students who use a laptop computer in the classroom report occasional email checking and frequent instant message sending and receiving. These students judged themselves to be less attentive during the lecture and to attain lower academic performance levels than other students [55\{Golub, 2010 $\# 23,56]$. It was also found that the self-assessments of students on failure to complete homework correlated significantly with their high usage of instant messaging software and specific types of multi-tasking activities [57] [31] [58]. Moreover, these behaviours interfered with schoolwork and was negatively related to overall college grade point average (GPA) performance [18] [59].

The debate regarding the effect of multitasking on academic performance has not yet come to a consensus [34] [60]. For instance, [30] observed 185 undergraduate students in three experimental conditions where learners were distracted with varying numbers of text messages. Findings showed that learning success decreased as the amount of texting increased. Another experimental study found that using mobile phones during lectures interfered with the learning gains of undergraduate students regardless of the degree of texting [61]. On the other hand, [62] designed a similar experiment with 120 university students where receiving instant messages or texting during video lectures did not have any effect on performance. Other studies have revealed a negative association between the frequency of multitasking in learning settings and GPA indicative of academic performance [63][[64][[11,31, 65].

\subsection{Conceptual Framework}

Literature portrays that ICT-induced multitasking is replete among students [5] [29] [1] [2]. It has been pointed out that technology-induced multitasking resides within the construct of attentional control [13], and within the broader framework of self-regulation [36]. Time management skill is an important aspect of behaviour for self-regulation [6] [66] and, as an intervening variable, may explain the influence of multitasking on academic performance [67]. If an individual has a good plan of what to do, he may not be distracted by other media activities. In addition, time management could buffer the negative effect of media multitasking [67]. Further, ICT-induced multitasking among students documents a number of distasteful consequences including hindered productivity at the expense of better academic performance [3] [4] [5] [6].
It is therefore apparent that ICT-induced multitasking influences academic performance among university students; through self-regulation, attention span, emotional control and productivity focus, as depicted in the Figure 1 which follows.

\begin{tabular}{|c|c|c|}
\hline $\begin{array}{l}\text { ICT- } \\
\text { induced } \\
\text { Multi- } \\
\text { tasking }\end{array}$ & $\begin{array}{l}\text { Self- } \\
\text { regulation } \\
\text { Attention } \\
\text { span } \\
\text { Emotional } \\
\text { control } \\
\text { Productivity } \\
\text { focus }\end{array}$ & $\begin{array}{l}\text { Academic } \\
\text { per- } \\
\text { formance }\end{array}$ \\
\hline
\end{tabular}

Figure 1: Conceptual framework for the effect of ICT-induced multitasking on student academic performance.

\subsection{Study Objectives}

The main objective of the study was to determine the effect that information and communication technology induced multitasking has on academic performance of university students in Uganda. Specifically, the study sought to investigate the following: the effect of ICT-induced multitasking on student attention; the influence of ICTinduced multitasking on student self-regulation; the consequence of ICT-induced multitasking on student productivity; how often students multitask during study session (say, during a one-hour lecture); whether ICTinduced multitasking is contagious among students; if student characteristics influence ICT-induced multitasking; whether ICT-induced multitasking impairs face-to-face interaction with others; and if ICT-induced multitasking is emotional-reward driven at the expense of better academic performance.

\section{METHODS}

To achieve the objectives of this study primary data were collected in May 2016 using stratified cluster sample design, through a self-reported questionnaire, from 312 Makerere University students. Students offering arts, sciences, male and female were targeted. Data were collected on the various characteristics under the constructs presented in the Figure 1 contained, with academic performance transformed into a binary outcome (good or poor).

\section{RESULTS}

Findings from the study are presented beginning with the characteristics of respondents, then the model for ICTinduced multitasking on academic performance.

\subsection{Characteristics of Students who Engage in ICT-induced Multitasking}

In the Table 1, a description of the characteristics of respondents of the study is made. From the Table 1 while 
attending lecture, 62 percent of students multitask. Slightly, fewer female students (48\%) multitask compared to their male counterparts (52\%). Sciences-based majors (74\%) do adversely multitask in comparison to their arts-based counterparts (27\%). In the middle of working on an assignment, 70 percent of students multitask. Students who have ever stayed up late to multitask were 60 percent while those who have ever woken up early to multitask were 43 percent. Students who multitask and have more friends online than face-to-face were 52 percent. Up to 89 percent of students engage in multitasking upon seeing fellow students so doing.

On self-regulation, 66 percent of students report that they possess good time management skills. Seventy (70) percent report that they have a clear idea of what they want to accomplish during each upcoming week, but only 47 percent do make a list of what they have to do each day. While 74 percent of students often desist from multitasking so as to allow themselves focus on academic work, only 62 percent of the students have enough time to complete their assignments as thoroughly as they would like to. Up to 55 percent of students sometimes multitask without a specific goal.

Regarding emotional control: 50 percent of students have ever spent time even when advisable not to. Seventy three (73\%) engage in multitasking to escape boredom and a similar percentage $(74 \%)$ believe that multitasking provides them enjoyment. However, 45 percent of students have ever felt apprehensive about the much time that they spend multitasking.

With respects to productivity, only 49 percent of students reported that multitasking helps them to be more productive in their study time and only 62 percent of students who multitask have enough time to complete their assignments as flawlessly as they would like to.

Furthermore, during a one-hour lecture, on average, students multitask (switch on-and-off tasks) five (5) times with the longest attention span on the lecture being 41 minutes. The average number of minutes a student spends multitasking during a one-hour (60 minute) lecture is 13 .

Table 1: Characteristics of university students who engage in ICT-induced multitasking

\begin{tabular}{|l|r|}
\hline General Characteristics & Percentage \\
\hline $\begin{array}{l}\text { 1. Students who multitask while } \\
\text { attending lecture. }\end{array}$ & 62.1 \\
\hline $\begin{array}{l}\text { 2. Female students who multitask while } \\
\text { attending lecture. }\end{array}$ & 47.8 \\
\hline 3. $\begin{array}{l}\text { Male students who multitask while } \\
\text { attending lecture. }\end{array}$ & 52.2 \\
\hline $\begin{array}{l}\text { 4. } \\
\text { Students of sciences-based major } \\
\text { who multitask while attending } \\
\text { lecture }\end{array}$ & 73.5 \\
\hline
\end{tabular}

\begin{tabular}{|c|c|}
\hline $\begin{array}{l}\text { 5. Students of arts-based major who } \\
\text { multitask while attending lecture. }\end{array}$ & 26.5 \\
\hline $\begin{array}{l}\text { 6. Students who multitask in the middle } \\
\text { of working on an assignment. }\end{array}$ & 70.3 \\
\hline $\begin{array}{l}\text { 7. Students who have ever stayed up } \\
\text { late to multitask. }\end{array}$ & 59.9 \\
\hline $\begin{array}{l}\text { 8. Students who have ever woken up } \\
\text { early to multitask. }\end{array}$ & 43.2 \\
\hline $\begin{array}{l}\text { 9. Students who report that multitasking } \\
\text { distracts them from academic work. }\end{array}$ & 45.7 \\
\hline $\begin{array}{l}\text { 10. Students who multitask and have } \\
\text { more friends online than face-to- } \\
\text { face. }\end{array}$ & 51.7 \\
\hline $\begin{array}{l}\text { 11. Students who find themselves } \\
\text { engaging in multitasking upon } \\
\text { seeing fellow students so doing. }\end{array}$ & 88.7 \\
\hline \multicolumn{2}{|l|}{ Self-regulation } \\
\hline $\begin{array}{l}\text { 12. Students who reported that they } \\
\text { possess good time management } \\
\text { skills. }\end{array}$ & 65.7 \\
\hline $\begin{array}{l}\text { 13. Students who have a clear idea of } \\
\text { what they want to accomplish } \\
\text { during each upcoming week. }\end{array}$ & 70.2 \\
\hline $\begin{array}{l}\text { 14. Students who make a list of things } \\
\text { they have to do each day. }\end{array}$ & 47.0 \\
\hline $\begin{array}{l}\text { 15. Students who have enough time to } \\
\text { complete their assignments as } \\
\text { thoroughly as they would like to. }\end{array}$ & 62.2 \\
\hline $\begin{array}{l}\text { 16. Students who often desist from } \\
\text { multitasking so as to allow } \\
\text { themselves focus on academic } \\
\text { work. }\end{array}$ & 74.1 \\
\hline $\begin{array}{l}\text { 17. Students who find it hard to resist } \\
\text { multitasking. }\end{array}$ & 45.9 \\
\hline $\begin{array}{l}\text { 18. Students who consider multitasking } \\
\text { to be to be a good study tool. }\end{array}$ & 52.1 \\
\hline $\begin{array}{l}\text { 19. Students who sometimes multitask } \\
\text { without a specific goal. }\end{array}$ & 54.5 \\
\hline Emotional Control & \\
\hline
\end{tabular}




\begin{tabular}{|c|c|c|}
\hline 20. & $\begin{array}{l}\text { Students who have ever spent time } \\
\text { multitasking even when advisable } \\
\text { not to. }\end{array}$ & 49.7 \\
\hline & $\begin{array}{l}\text { Students who sometimes engage in } \\
\text { multitasking to escape boredom. }\end{array}$ & 72.9 \\
\hline & $\begin{array}{l}\text { Students who believe multitasking } \\
\text { provides them enjoyment. }\end{array}$ & 73.7 \\
\hline 23. & $\begin{array}{l}\text { Students who become frustrated } \\
\text { when conditions do not permit } \\
\text { multitasking. }\end{array}$ & 55.0 \\
\hline 24. & $\begin{array}{l}\text { Students who become irritable } \\
\text { when conditions do not permit } \\
\text { multitasking. }\end{array}$ & 49.3 \\
\hline 25. & $\begin{array}{l}\text { Students who have ever engaged in } \\
\text { multitasking even when they feel } \\
\text { not to. }\end{array}$ & 54.1 \\
\hline 26. & $\begin{array}{l}\text { Students who have ever felt } \\
\text { apprehensive about the much time } \\
\text { they spend multitasking. }\end{array}$ & 45.2 \\
\hline \multicolumn{3}{|c|}{ Productivity } \\
\hline 27. & $\begin{array}{l}\text { Students who report that } \\
\text { multitasking helps them to be more } \\
\text { productive in their study time. }\end{array}$ & 48.8 \\
\hline 28. & $\begin{array}{l}\text { Students who have enough time to } \\
\text { complete their assignments as } \\
\text { thoroughly as they would like to. }\end{array}$ & 62.2 \\
\hline Atte & ention span & \\
\hline 29. & $\begin{array}{l}\text { The number of times students } \\
\text { multitask (switch on-and-off tasks) } \\
\text { during a one-hour lecture. }\end{array}$ & 5.4 \\
\hline & $\begin{array}{l}\text { On average, the longest duration (in } \\
\text { minutes) during a one-hour ( } 60 \\
\text { minutes) lecture that a student can } \\
\text { go without multitasking. }\end{array}$ & 40.7 \\
\hline & $\begin{array}{l}\text { Average number of minutes a } \\
\text { student spends multitasking during } \\
\text { a one-hour ( } 60 \text { minute) lecture. }\end{array}$ & 12.5 \\
\hline
\end{tabular}

Consequent to the conceptual framework presented in the Figure 1, structural equation modelling was moved in order to concurrently study the indirect effect of ICT-induced multitasking (independent variable) on academic performance (dependent variable) through one's selfregulation, productivity focus and attention span (intermediate variables). The model equations were then:

$$
\begin{aligned}
& \text { self } f_{\text {reg }}=\alpha_{1}+\beta_{1} \text { multi }+e_{\text {self }} \text { reg } \\
& \text { atten }_{\text {span }}=\alpha_{2}+\beta_{2} \text { multi }+e_{\text {atten }_{\text {span }}} \\
& \text { Emotn }_{\text {contol }}=\alpha_{3}+\beta_{3} \text { multi }+e_{\text {emotn }_{\text {control }}} \\
& \text { prod }=\alpha_{4}+\beta_{4} \text { multi }+e_{\text {prod }} \\
& \text { acad }_{\text {perf }}=\alpha_{5}+\beta_{5} \text { self }_{\text {reg }}+\beta_{6} \text { atten }_{\text {span }} \\
& +\beta_{7} \text { emotn }_{\text {control }}+\beta_{8} \text { prod } \\
& +e_{\text {acad }_{\text {perf }}}
\end{aligned}
$$

\subsection{Structural Equation Model for

\begin{tabular}{|c|c|c|c|c|}
\hline \multicolumn{2}{|c|}{ Potential Factors } & \multirow[t]{2}{*}{$\begin{array}{l}\text { Coeffi } \\
\text { cients }\end{array}$} & \multirow[t]{2}{*}{$\begin{array}{l}\text { Odds } \\
\text { Ratio } \\
\end{array}$} & \multirow[t]{2}{*}{$\mathbf{P}>|\mathbf{z}|$} \\
\hline $\begin{array}{ll}\text { Self- } & \\
& \text { re } \\
& \text { gu } \\
& \text { lat } \\
& \text { io } \\
& \mathrm{n} \\
\end{array}$ & $<-$ & & & \\
\hline & Multitasking & -0.853 & 0.426 & 0.004 \\
\hline \multirow[t]{2}{*}{$\begin{array}{l}\text { Attention } \\
\text { span }\end{array}$} & $<-$ & & & \\
\hline & Multitasking & -7.112 & 0.001 & 0.006 \\
\hline \multirow[t]{2}{*}{ Productivity } & $<-$ & & & \\
\hline & Multitasking & -8.717 & 0.001 & 0.005 \\
\hline \multirow[t]{2}{*}{$\begin{array}{l}\text { Emotional } \\
\text { control }\end{array}$} & then & & & \\
\hline & Multitasking & -1.098 & 0.334 & 0.000 \\
\hline \multirow[t]{5}{*}{$\begin{array}{l}\text { Academic } \\
\text { Performance }\end{array}$} & $<-$ & & & \\
\hline & Self-regulation & 0.342 & 1.408 & 0.213 \\
\hline & Attention span & -0.004 & 0.996 & 0.514 \\
\hline & Productivity & 0.002 & 1.002 & 0.772 \\
\hline & $\begin{array}{l}\text { Emotional } \\
\text { control }\end{array}$ & 0.052 & 1.054 & 0.647 \\
\hline
\end{tabular} Predictors of Academic Performance}

Following from the conceptual framework presented in Figure 1, results of structural equation modelling are presented in Table 2.

Table 2: Structural equation model of ICT-induced multitasking on academic performance

From the Table 2, ICT-induced multitasking is seen to negatively significantly $(\mathrm{p}<0.05)$ affect academic performance through self-regulation, attention span, productivity and emotional control. 
On self-regulation, 0.426 decrease in the log-odds of selfregulation is expected for students who multitask during academic engagement compared to those who do not. Holding all other independent variables constant, an increase in academic performance of students who possess a higher degree of self-regulation is expected.

With regards to attention span, 0.001 decrease in the logodds of attention span is expected for students who multitask compared to those who do not; holding all other independent variables constant consequently, resulting into a decrease in academic performance for students who multitask.

On productivity, notable 0.001 decrease in the log-odds of productivity is expected for students who multitask compared to those who do not. Holding all other independent variables constant, an increase in academic performance for students who focus on productivity but not multitasking is expected.

Regarding emotional control, 0.334 decrease in the logodds of emotional control is expected for students who multitask compared to those who do not. Holding all other independent variables constant consequently there will be an increase in academic performance for students as their level of emotional control increases.

\section{DISCUSSION}

This study focused on the effect of information and communication technology induced multitasking on academic performance of university students in Uganda. Indeed, ICT-induced multitasking is replete among students [5] [29] [1] [2]. Findings of this study show that 62 percent of university students multitask while attending lectures. Regarding multitasking, on average, students switch tasks five (5) times during a one-hour lecture. To switch tasks five (5) times while attending a one-hour lecture is indeed to do so often; which is in tandem with observation by [1], that Students tend to multitask very often during learning activities. The study by [27] which demonstrated that 'students switch tasks an average of 27 times per hour,' does not specifically focus on the particular type of multitasking. This study, however, specifically focuses on ICT-induced multitasking while attending lecture. Also, observed in this study is that slightly fewer female students (48\%) multitask compared to their male counterparts $(52 \%)$. This may not necessarily mean that female students multitask less but may only be in the case of agreement with [33], who found that females do handle multitasking better than males.

Sciences-based majors (74\%) do adversely multitask in comparison to their arts-based counterparts (27\%). The large disparity may be because science-based majors are more apt to grow into digital natives in comparison to artsbased majors because the content of what sciences-based majors study is closely or is directly and practically related to ICT.

It was also noted that up to 89 percent of students engage in multitasking upon seeing fellow students so doing, which likely implies that ICT-induced multitasking is contagious. Furthermore, [59] found that students seated near multitasking peers were consistently distracted and performed worse on retention measures compared to those sitting near students who were not multitasking. Therefore, being physically close to a multitasking peer is likely to negatively affect ones academic performance.

Although 70 percent of students reported that they have a clear idea of what they want to accomplish during each upcoming week, only 47 percent do make a list of what they have to do each day, which likely implies that a number of students lack attentional control [13] and, therefore, selfregulation [36] which in turn negatively correlates with poor academic performance. Moreover, this study found that up to 55 percent of students sometimes multitask without a specific goal.

With respect to self-regulation, ICT-induced multitasking was observed to negatively affect academic performance, yet self-regulation involves setting goals, prioritizing, time estimation and problem solving [6] [66], which are significant for good academic performance. With regards to attention span, this study found out that, through attention span, multitasking negatively influences academic performance which also [21] observed. Furthermore, multitasking is often characterized by staying up late at night [22], which often positively correlates with lower levels of academic success [23]. With so much mentioned, obviously multitasking lowers productivity.

Nonetheless, multitasking does not always have negative consequences and may even have beneficial cognitive outcomes [15]. Indeed, this study found out that up to 74 of university students report that multitasking provides them enjoyment. Multitasking was noted to positively be correlated with university students' emotional satisfaction, albeit at the cost of cognitive performance [40]. To be fair, multitasking is necessary for certain professions and is an indisputable phenomenon in education and life [13]. Multitasking can be an efficient use of time; a relatively manageable endeavour when necessary; or, when well monitored or well-regulated, an effective tool in problem solving [41] [68]. Furthermore, people who are hyperconnected generally report that they do not have problems attending to everyday tasks and inter-personal relationships [44]. It may be a question of changing nature of norms, traditionally people were expected to give and receive undivided attention when talking in face-to-face conversation with another, yet new norms are being developed for the networked society, such as responding to text messages promptly [45, 69].

Up to 62 percent of university students multitask while attending lectures. On average, students switch tasks five (5) times during a one-hour lecture. Slightly fewer female students $(48 \%)$ were noted to multitask during study time 
compared to their male counterparts (52\%). Sciences-based majors $(74 \%)$ do multitask more compared to their artsbased counterparts (27\%). Moreover, up to 89 percent of students engage in multitasking upon seeing fellow students so doing which likely implies that ICT-induced multitasking is contagious.

Nonetheless, multitasking does not always have negative consequences and may even have beneficial cognitive outcomes. Indeed, this study found out that up to 74 of university students report that multitasking provides them enjoyment; which positively correlates with university students' emotional satisfaction, which is normally healthy for better academic performance. Indeed, multitasking can be an efficient use of time when well regulated and an effective tool in problem solving. Multitasking may only be indicative of the changing nature of norms. Traditionally people were expected to give and receive undivided attention when talking in face-to-face conversation with another; yet new norms are being developed for the networked society, such as responding to text messages promptly. To buffer the negative effect of ICT-induced multitasking on academic performance, institutions of higher learning need to provide an environment where students are monitored for a good degree of self-regulation, attention span, emotional control and productivity focus.

\section{CONCLUSION}

This study noted that ICT-induced multitasking does not affect academic performance directly but through selfregulation, attention span, emotional control and productivity focus.

Noting that ICT-induced multitasking affects academic performance through self-regulation, attention span, emotional control and productivity focus, to buffer the negative effect of ICT-induced multitasking on academic performance university students need be facilitated to possess a high degree of self-regulation, attention span, emotional control and productivity focus. Multitasking during lectures should specifically be discouraged, since ICT-induced multitasking tends to be contagious. Since multitasking does not always have a negative consequence, it may not be completely discouraged, given that many do derive emotional satisfaction through it. Provided it is properly regulated, multitasking is beneficial for better academic performance. Therefore, the future scope of the studies should focus on developing model frameworks that supports integration of ICT-induced multitasking that directly supports students' better academic performance.

\section{REFERENCES}

[1] C. Calderwood, P. L. Ackerman, and E. M. Conklin, "What else college students "do" while studying? an investigation of multitasking," Computers in Human Behavior, vol. 75, 2014.
[2] J. H. Kuznekoff and S. Titsworth, "The impact of mobile phone usage on student learning," Communication Education, vol. 62, pp. 233-252, 2013.

[3] A. Salomon and Y. B. Kolikant, "High-school students' perceptions of the effects of nonacademic usage of ICT on their academic achievements," Computers in Human Behavior, vol. 64, p. 143e151, 2016.

[4] A. Kononova, E. Joo, and S. Yuan, "If I choose when to switch: Heavy multitaskers remember online content better than light multitaskers when they have the freedom to multitask," Computers in Human Behavior, vol. 65, p. 567e575, 2016.

[5] C. A. Terry, P. Mishra, and C. J. Roseth, "Preference for multitasking, technological dependency, student metacognition, \& pervasive technology use: An experimental intervention," Computers in Human Behavior vol. 65, p. 24e251, 2016.

[6] Y. Zhang and P. P. Rau, "An Exploratory Study to Measure Excessive Involvement in Multitasking Interaction with Smart Devices," Cyberpsychology, Behavior, and Social Networking, vol. 19, 2016.

[7] A. Lepp, J. E. Barkley, and A. C. Karpinski, "The relationship between cell phone use, academic performance, anxiety, and satisfaction with life in college students," Computers in Human Behavior, vol. 31, 2014.

[8] T. Judd, "Making sense of multitasking," The role of Facebook. Computers \& Education, vol. 70, pp. 194-202, 2014.

[9] F. Sana, T. Weston, and N. J. Cepeda, "Laptop multitasking hinders classroom learning for both users and nearby peers," Computers \& Education, vol. $62,2013$.

[10] N. Unsworth, B. D. McMillan, G. Brewer, and G. J. Spillers, "Everyday attention failures: An individual differences investigation," Journal of Experimental Psychology: Learning, Memory, and Cognition, vol. 38, p. 1765e1772, 2012.

[11] J. M. Kraushaar and D. C. Novak, "Examining the affects of student multitasking with laptops during the lecture," Journal of Information Systems Education, vol. 21, p. 241e251, 2010.

[12] L. D. Rosen, A. F. Lim, L. M. Carrier, and N. A. Cheever, "An empirical examination of the educational impact of text message-Induced task switching in the classroom: Educational implications and strategies to enhance learning," Psicologia Educativa, vol. 17, p. 163e177, 2011.

[13] E. Wood and L. Zivcakova, "Understanding multimedia multitasking in educational settings," In L. D. Rosen, N. A. Cheever, \& L. Mark Carrier (Eds.), Wiley handbook of psychology, technology, and society, p. 404e453, 2015.

[14] A. Cabanac, L. Perlovsky, and M. BonniotCabanac, "Music and academic performance," Behavioural Brain Research, vol. 256, pp. 257260, 2013.

[15] J. Winter, D. Cotton, J. Gavin, and J. D. Yorke, "Effective e-learning? Multi-tasking, distractions and boundary management by graduate students in an online environment," 2010. 
H. Kauffman, "A review of predictive factors of student success in and satisfaction with online learning," Research in Learning Technology, vol. 2015, p. 26507, 2015.

[17] H. Hembrooke and G. Gay, "The laptop and the lecture: The effects of multitasking in learning environments," Journal of computing in higher education, vol. 15, p. 46e64, 2003.

[18] S. Bellur, K. L. Nowak, and K. S. Hull, "Make it our time: In class multitaskers have lower academic performance," Computers in Human Behavior, vol. 53, 2015.

[19] G. Bozeday, "Media multitasking and the student brain," School Specialty, 2013.

[20] T. F. Heatherton and D. D. Wagner, "Cognitive neuroscience of self-regulation failure," Trends in Cognitive Sciences, vol. 15, p. 132e139, 2011.

[21] F. Y. F. Wei, Y. K. Wang, and M. Klausner, "Rethinking college students' self-regulation and sustained attention: Does text messaging during class influence cognitive learning?," Communication Education, vol. 61, p. 185e204, 2012.

[22] W. A. Austin and M. W. Totaro, "Gender differences in the effects of Internet usage on high school absenteeism," The Journal of SocioEconomics, vol. 40, 2011.

[23] H. C. Tsai and S. H. Liu, "Relationships between time-management skills, Facebook interpersonal skills and academic achievement among junior high school students," Social Psychology of Education, p. 1e14, 2015.

[24] E. Ophir, C. Nass, and A. D. Wagner, "Cognitive control in media multitaskers," PNAS, vol. 1e5, 2009.

[25] J. R. Finley, A. S. Benjamin, and J. S. McCarley, "Metacognition of multitasking: How well do we predict the costs of divided attention? ," Journal of Experimental Psychology: Learning, Memory, and Cognition, vol. Applied, 20, p. 158e165, 2014.

[26] X. Wang, "Excelling in multitasking and enjoying the distraction: Predicting intentions to send or read text messages while driving," Computers in Human Behavior, vol. 64, p. 584e590, 2016.

[27] C. Marci, "A (biometric) day in the life: Engaging across media," Paper presented at Re: Think 2012, New York, NY, 2012, March.

[28] Y. Fan, S. Gong, Y. Wang, and Z. Wang, "Advances in Psychology," vol. 6, pp. 914-922, 2016.

[29] K. Sim, N.; and S. Stein, "Reaching the unreached: de-mystifying the role of ICT in the process of doctoral research," Research in Learning Technology vol. 2016, p. 307172016.

[30] L. D. Rosen, M. L. Carrier, and N. A. Cheever, "Facebook and texting made me do it: Mediainduced task-switching while studying," Computers in Human Behavior, vol. 29, p. 948e958, 2013.

[31] R. Junco and S. R. Cotten, "No A 4 U: the relationship between multitasking and academic performance," Computers \& Education, vol. 59, p. $505 \mathrm{e} 514,2012$.

[32] K. M. Lister-Landman, S. E. Domoff, and E. F. Dubow, "The Role of Compulsive Texting in Adolescents' Academic Functioning," Psychology of Popular Media Culture. Advance online publication, 2015.

[33] G. Stoet, D. B. O'Connor, M. Conner, and K. R. Laws, "Are women better than men at multitasking?," BMC Psychology, p. 1:18, 2013.

[34] S. Xu, Z. Wang, and P. David, "Media multitasking and well-being of university students," Computers in Human Behavior, vol. 55, p. 242e250, 2016.

[35] F. Y. Hong, S. I. Chiu, and D. H. Hong, "A model of the relationship between psychological characteristics, mobile phone addiction and use of mobile phones by Taiwanese university female students," Computers in Human Behavior, vol. 28, pp. 2152-2159, 2012.

[36] M. S. Hagger, C. Wood, C. Stiff, and N. L. D. Chatzisarantis, "Ego depletion and the strength model of self-control," A meta-analysis. Psychological Bulletin, vol. 136, p. 495e525, 2010.

[37] C. B. Fried, "In-class laptop use and its effects on student learning," Computers \& Education, vol. 50, p. 906e914, 2008.

[38] S. Misra, L. Cheng, J. Genevie, and M. Yuan, "The iPhone effect: the quality of in-person social interactions in the presence of mobile devices " Environment and Behavior. Advance online publication, 2014.

[39] S.-I. Shih, "A null relationship between media multitasking and well-being," PLoS One, vol. 8, p. e64508, 2013.

[40] Z. Wang and J. M. Tchernev, "The "myth" of media multitasking: Reciprocal dynamics of media multitasking, personal needs, and gratifications," Journal of Communication, vol. 62, p. 493e513, 2012.

[41] S. A. Brasel and J. Gips, "Media multitasking behavior: Concurrent television and computer usage," Cyberpsychology, Behavior and Social Networking, vol. 14, p. 527e534, 2011.

[42] P. David, L. Xu, J. Srivastava, and J. Kim, "Media multitasking between two conversational tasks," Computers in Human Behavior, vol. 29, 2013.

[43] A. Arndt, T. J. Arnold, and T. D. Landry, "The effects of polychromic-orientation upon retail employee satisfaction and turnover," Journal of Retailing, vol. 82, 2006.

[44] A. Smith, "The best (and worst) of mobile connectivity," Washington, DC: Pew Research Center, 2012.

[45] D. K. Forgays, I. Hyman, and J. Schreiber, "Texting everywhere for everything: gender and age differences in cellphone etiquette and use " Computers in Human Behavior, vol. 31, 2014.

[46] J. L. Badge, N. F. W. Saunders, and A. J. Cann, "Beyond marks: new tools to visualise student engagement via social networks," Research in Learning Technology, vol. 20, 2012. 
[47] M. Prensky, "Digital natives, digital immigrants, part 1," On The Horizon, vol. 9, 2001.

[48] T. Cochrane, L. Antonczak, H. Keegan, and V. Narayan, "Riding the wave of BYOD: developing a framework for creative pedagogies," Research in Learning Technology, vol. 2014, p. 24637 2014.

[49] W. Veen and B. Vrakking, "Homo zappiens: Growing up in a digital age," London, UK. Network Continuum Education, 2006.

[50] C. Cronin, T. Cochrane, and A. Gordon, "Nurturing global collaboration and networked learning in higher education," Research in Learning Technology, vol. 2016, p. 26497, 2016.

[51] Q. J. Anderson and L. Rainie, "Millennials will benefit and suffer due to their hyperconnected lives," Pew Internet \& American Life Project, 2012.

[52] S. Kessler, "38\% of college students can't go 10 minutes without tech [STATS]," Mashable Tech, 2011.

[53] W. Barrat, M. Hendrickson, A. Stephens, and J. Torres, "The Facebook: Computer mediated social networking," Student Affairs Online, vol. 6, p. 1e5, 2005.

[54] L. E. Levine, B. M. Waite, and L. L. Bowman, "Electronic media use, reading, and academic distractibility in college youth," Cyberpsychology \& Behavior, vol. 10, p. 560e566, 2007.

[55] M. Duggan and L. Rainie, "Cell phone activities 2012," Pew Internet \& American Life Project, 2012.

[56] T. L. Golub and M. Miloloza, "Facebook, academic performance, multitasking and selfesteem," In 10th special focus symposium on ICESKS: Information, communication and economic sciences in the knowledge society, 2010.

[57] M. A. Moreno, L. Jelenchick, R. Koff, J. Eikoff, C. Diermyer, and D. A. Christakis, "Internet use and multitasking among older adolescents: An experience sampling approach," Computers in Human Behavior, vol. 28, p. 1097e1102, 2012.

[58] R. E. Mayer and R. Moreno, "Nine ways to reduce cognitive load in multimedia learning," Educational Psychologist, vol. 38, p. 43e52, 2003.

[59] D. K. Wentworth and J. H. Middleton, "Technology use and academic performance," Computers \& Education, vol. 78, p. 306e311, 2014.

[60] M. L. Courage, "Translational science and multitasking: Lessons from the lab for the everyday world," Developmental Review vol. 35 pp. 1-4, 2016.

[61] Y. Ellis, B. Daniels, and A. Jauregui, "The effect of multitasking on the grade performance of business students," Research in Higher Education Journal, vol. 8, 2010.

[62] D. R. Lawson, "The effects of text messaging on memory recall in college Learning and Instruction students," North Carolina: Western Carolina University. Unpublished PhD dissertation, vol. 41, p. 94e105, 2013.
[63] S. M. Ravizza, D. Z. Hambrick, and K. M. Fenn, "Non-academic internet use in the classroom is negatively related to classroom learning regardless of intellectual ability," Computers \& Education, vol. 78, 2014.

[64] L. Burak, "Multitasking in the university classroom," International Journal for the Scholarship of Teaching And Learning, vol. 6, 2012.

[65] W. C. Jacobsen and R. Forste, "The wired generation: academic and social outcomes of electronic media use among university students," Cyberpsychology, Behavior, and Social Networking, vol. 14, p. 275e280, 2011.

[66] P. R. Pintrich, "Multiple goals, multiple pathways: The role of goal orientation in learning and achievement," Journal of Educational Psychology, vol. 92, p. 544, 2000.

[67] X. Yang, X. Xu, and L. Zhu, "Media multitasking and psychological wellbeing in Chinese adolescents: Time management as a moderator," Computers in Human Behavior, vol. 53, pp. 216222, 2015.

[68] L. Lin, "Breadth-biased versus focused cognitive control in media multitasking behaviors," Proceedings of the National Academy of Sciences, vol. 106, p. 15521e15522, 2009.

[69] L. Rainie and B. Wellman, "Networked: The new operating system," The MIT Press, 2012. 